\title{
Ayo Menikah (Muda)! : Mediatisasi Ajaran Islam di Media Sosial
}

\author{
Izmy Khumairoh \\ Pascasarjana Universitas Gadjah Mada \\ izmy.khu@gmail.com
}

\begin{abstract}
This article analyzes the close relationship between religion (i.e. religious discourses in the context of everyday life) and modernization (i.e. the intensive and excessive use of social media in society). This article is based on literature and social media review - in particular it reviews on how the role of religion changed drastically due to mediatization process that occurs in the public sphere; as well as how the social media plays a dynamic role in society. This article concludes that the new image of religion as shown in mass media and social media demonstrates its shifting power from traditional institutions to mass and social media. Religious value immerses into every aspect of the everyday life and the religious aura; and this phenomenon neglects the secularization theory.
\end{abstract}

Keywords: anthropology, social media, marriage, Islam

\begin{abstract}
Abstrak
Artikel ini menganalisis hubungan erat antara agama (yaitu wacana keagamaan dalam konteks kehidupan sehari-hari) dan modernisasi (yaitu penggunaan media sosial yang intensif dan eksesif dalam masyarakat). Analisis berdasar pada studi literatur dan observasi di dunia maya - termasuk beberapa akun media sosial dan interaksi antara netizen - terutama bahasan mengenai perubahan peran agama yang drastis akibat proses mediatisasi yang di ranah publik; sebagaimana media memainkan peran dinamis dalam masyarakat. Artikel ini menyimpulkan bahwa citra baru agama, yang terpampang di media massa dan media sosial, mencerminkan pergeseran kekuasaan agama dari institusi tradisional ke media. Nilainilai agama terus menemukan celah untuk memasuki setiap aspek kehidupan dan mencakup aspek aura agama sehingga fenomena ini tidak sesuai dengan teori sekulerisasi.
\end{abstract}

Kata kunci: antropologi, media sosial, pernikahan, Islam

\section{Pendahuluan}

Indonesia adalah salah satu dari sedikit negara yang mampu melalui fase modernisasi tanpa terjebak dalam dua kutub ekstrem (merangkul Westernisas atau menolak mentah-mentah westernisasi dengan wacana radikalisme dan fundamentalisme). Kepiawaian Indonesia dalam hal ini ditunjukkan dengan sejalannya gagasan demokrasi dan Pancasila yang sekuler dengan gagasan Islamisasi yang menyentuh setiap aspek kehidupan, kecuali di aspek legalpolitis. Indonesia sebagai negara dengan umat

Muslim terbesar di dunia menjadi acuan bagi keseimbangan antara gaya hidup modernsekuler dan identitas Islam. Peran yang dimainkan oleh agama di Indonesia berbeda dengan apa yang dikemukakan oleh teori sekulerisasi, terutama ramalan Weber yang mengatakan bahwa masyarakat kontemporer semakin lama akan semakin menyerupai 'kerangkeng besi' yang memerangkap individu dalam efisiensi, kalkulasi, dan kontrol yang 
rasional (Weber, 1958). Berkebalikan dengan teori sekulerisasi, agama di Indonesia terusmenerus membangun dan membentuk pemahaman dalam aspek-aspek kehidupan bermasyarakat, terutama dalam aspek politik melalui kampanye, pencitraan, program pemerintah, kebijakan publik. Dengan kata lain, agama di Indonesia bersifat tradisional sekaligus modern.

Saat ini sedang terjadi pergeseran sosial di masyarakat yaitu maraknya budaya massa. Hampir tidak ada satu pun aspek kehidupan manusia yang luput dari pengaruh budaya massa, tak terkecuali agama. Hal ini ditandai dengan merosotnya peran-peran tradisional dari institusi agama. Kejadian ini berlangsung secara episodik dalam satu momen tertentu, dan berlangsung tanpa konflik (dan oleh karenanya: tanpa ruang bagi perenungan dan dialog dua arah) (Adorno, 2006).

Pemaknaan agama diambil alih oleh media sosial dan institusi agama tradisional semakin merosot perannya; kehidupan spiritual pun termediatisasi. Media sosial memainkan peran penting dalam ritualisasi aspek-aspek kehidupan beragama; dengan kata lain, saat ini aspek-aspek keagamaan memperoleh legitimasinya dari pesan-pesan berbalut aura agama yang bertebaran di media sosial.

Artikel ini berupaya menganalisis hubungan antara 'yang tradisional' (agama) dan 'yang modern' (media sosial), dan menunjukkan dampak dari proses mediatisasi terhadap penyebaran pesan-pesan keagamaan (dalam kasus ini: Islam) dan pemaknaannya mediatisasi tersebut oleh individu-individu dalam masyarakat. Artikel ini menyoroti fenomena pernikahan muda yang marak dipromosikan melalui media sosial sebagai contoh kasus.

\section{Kajian Pustaka}

\section{Pernikahan, Agama, dan Media}

Pernikahan, adalah salah satu dari rangkaian ritual fundamental penanda kedewasaan.
Pernikahan dilakukan ketika seseorang dianggap sudah cukup umur untuk melegalkan hubungan interpersonal, baik secara sipil ataupun agama. Namun, di dalam praktiknya, keputusan untuk menikah sering kali dibuat tidak hanya oleh individu saja tetapi juga atas dorongan dari keluarga, maupun tekanan sosiokultural. Istilah 'perawan tua' misalnya, adalah sebuah stigma yang diciptakan masyarakat dan digunakan sebagai alat tekanan sosiokultural bagi individu yang terlambat menikah. Selain stigma, tekanan sosial juga disajikan dalam bentuk tradisi 'mengabdi dan balas budi kepada orangtua', yaitu dengan cara menikah. Tekanan sosial juga diciptakan dengan menggunakan perspektif agama, yaitu anjuran melakukan pernikahan sebagai sarana beribadah. Ungkapan pernikahan sebagai ladang pahala dan penyempurnaan nilai keagamaan seseorang (dengan surga sebagai imbalannya) adalah salah satu bentuk tekanan sosial yang diciptakan masyarakat.

Secara historis, sebelum hadirnya institusi keagamaan, sesungguhnya manusia telah mengenal konsep pernikahan. Pada masyarakat pemburu-peramu misalnya, praktik pernikahan dilakukan manusia dengan melakukan hubungan monogami yang didasari oleh asas pertukaran yang bersifat ekonomi (Marlowe, 2003). Praktik matrimoni pada masyarakat kesukuan diatur sedemikian rupa untuk kepentingan bersama, yaitu menjaga keberlangsungan hidup suku dan sebagai dasar pengaturan akses pada sumber daya alam yang langka. Laki-laki yang telah diinisiasi dan menjalani ritus peralihan dapat dengan mudah melintasi lahan suku musuh/lintas-sepupu, baik untuk mencari makanan ataupun pasangan. Melalui ritus peralihan, laki-laki otomatis mendapatkan 'hak istimewa' untuk diterima langsung dengan baik oleh suku lain atas dasar pemenuhan kebutuhan bagi kedua pihak (Reed, 2011).

Saat masyarakat manusia mulai mengenal sistem pertanian dan beralih menjadi masyarakat petani; pernikahan mulai diatur oleh unit sosial terkecil, yaitu keluarga, dan bersifat matrilineal. Pertukaran ekonomi pada masa itu dilakukan karena ketergantungan 
suami pada saudara laki-laki dari pihak istri. Praktik susu ${ }^{1}$ di Melanesia "mengharuskan laki-laki bercocok tanam untuk kepentingan saudara perempuannya, dan saudara laki-laki dari pihak istri akan melakukan hal yang sama pada dirinya” (Hoebel, 1949: 446). Namun, pertukaran antara pihak suami dengan saudara laki-laki dari istri tidak selalu bersifat linier; terkadang, salah satu pihak kembali dengan tangan kosong. Malinowski menyebut fenomena ketidaksetaraan dalam pertukaran ini dengan istilah chasse-croise, bahwa pertukaran makanan tidak menunjukkan kepentingan ekonomi serta meningkatkan friksi dan ketegangan antar lelaki (Malinowski, 1926: 37).

Bentuk peradaban manusia semakin kompleks, populasi menjadi semakin terpusat, dan pembagian kerja membuat sistem ekonomi pun turut berkembang. Evolusi kepemilikan pribadi adalah manifestasi bentuk kecemburuan lakilaki di masa kejayaan matriarki. Engels (2010) menyatakan bahwa terdapat peralihan pewarisan alat produksi dalam masyarakat petani, yang awalnya berada di tangan perempuan lalu beralih ke tangan anak lakilaki. Peristiwa ini lantas turut mengubah pengaturan garis keturunan pada masyarakat petani, semula matrilineal menjadi patrilineal. Dengan demikian, sistem dan pengaturan ekonomi dalam sebuah rumah tangga dapat dipegang penuh oleh laki-laki sehingga perempuan akhirnya terpisah dari berbagai kegiatan ekonomi.

Ajaran agama mulai masuk ke ranah pernikahan pada masa penafsiran firmanfirman Tuhan. Di masa awal kemunculan agama Kristen di wilayah Romawi, muncul ajaran bahwa pernikahan dapat menghambat keselamatan spiritual seseorang, sehingga gaya hidup selibat lebih dianjurkan. Namun, umat

\footnotetext{
${ }^{1}$ Susu adalah istilah untuk kelompok kekerabatan berdasarkan garis keturunan dari pihak ibu (matrilateral) di Melanesia. Kepemilikan alat produksi dipegang dan diwariskan pada pihak susu kecuali bagi laki-laki yang telah menikah (pindah suku). Walaupun demikian, laki-laki yang telah menikah masih bertanggung jawab atas urusan pemenuhan kebutuhan rumah tangga di keluarga asal (anggota susu).
}

Kristen saat itu diperbolehkan untuk berhubungan seks dengan tujuan prokreasi tanpa perlu pernikahan, asalkan tidak bersifat inses (Coontz, 2005). Melihat konteks di Romawi pada saat itu, ambivalensi mengenai makna pernikahan dalam ajaran Kristen dapat dipahami sebagai bentuk akulturasi dari transisi Kristenisasi kerajaan Romawi di bawah Konstantinopel. Kerajaan Romawi sendiri melegalkan adanya pernikahan sebagai bentuk legitimasi terhadap harta warisan. Semenjak berkuasa di Romawi, akhirnya Kristen meneruskan kontrol kerajaan terhadap pernikahan sebagai bentuk penerapan sistem hukum Code of Justinian. Ketika kerajaan mulai goyah karena serangan luar, gereja lalu mengambil alih peran legalisasi pernikahan. Martos mengatakan bahwa sebelum abad ke-11, tidak ada upacara pernikahan umat Kristen yang diselenggarakan di gereja. Pada abad pertengahan pun, tidak ada satu pun ritual gereja untuk memperingati upacara pernikahan umat Kristen. Namun, pada abad ke-12, pernikahan mulai menjadi bagian upacara yang harus diperingati, dan beberapa kemudian, pernikahan dicantumkan dalam Alkitab sebagai bagian dari 7 upacara ritual umat Kristen (Martos, 1982).

Di dalam tradisi Islam, pernikahan dilakukan sebagai bentuk realisasi dari salah satu kewajiban umat Muslim. Pernikahan disebut sebagai bagian dari sunnah Rasul. Umat wajib yang mampu wajib untuk menikah. Keluarga dianggap sebagai unit fundamental dalam ajaran Islam, sehingga umat Muslim dianjurkan untuk melakukan pernikahan sebagai suatu sarana untuk menciptakan keluarga Muslim. Selain itu, pernikahan juga dimaknai sebagai mekanisme utama dalam proses melestarikan dan menghidupkan masyarakat Muslim (Lo \& Aziz: 2009). Urgensi keberadaan keluarga dalam ajaran Islam telah disabdakan oleh Nabi Muhammad lewat pernyataan berikut:

"Menikahlah kalian dengan wanita yang penyayang lagi subur, karena (pada hari kiamat nanti) aku membanggakan banyaknya jumlah kalian di hadapan 
umat-umat yang lain” (HR. Abu Dawud).

Faktor finansial yang seringkali menjadi penghalang seseorang dalam menunaikan pernikahan tidak disarankan menjadi alasan yang menghambat seorang Muslim untuk menikah. Umat Muslim dianjurkan untuk percaya bahwa Allah akan mencukupkan rezeki bagi siapa pun yang melakukan pernikahan. Hal ini tercantum di dalam Al Qur'an:

"Dan kawinkanlah orang-orang yang sendirian di antara kamu, dan orangorang yang layak dari hamba-hamba sahayamu yang lelaki dan hambahamba sahayamu yang perempuan. Jika mereka miskin, Allah akan memampukan mereka dengan kurniaNya. Dan Allah Maha Luas lagi Maha Mengetahui” (Q.S. An-Nur : 32).

Balasan yang dijanjikan Allah dari sebuah pernikahan dan reproduksi merupakan salah satu simbol dari anjuran menunjukkan keimanan seorang Muslim sejati melalui pernikahan.

Faktor lain yang membuat pernikahan menjadi aspek penting dalam umat Muslim adalah larangan keras untuk menjalani kehidupan selibat. Sabda Nabi Muhammad mengenai hal ini berbunyi:

"Menikah itu bagian dari sunnahku, maka siapa yang tidak beramal dengan sunnahku, ia bukanlah dari golonganku” (HR. Ibnu Majah).

Kehidupan membujang dan menanggalkan keduniawian yang dipilih semata-mata sebagai upaya totalitas dalam beribadah dianggap sebagai tindakan yang berlebihan dan tidak disukai oleh Allah, seperti dalam firman-Nya berikut ini:

"Hai orang-orang yang beriman! Jangan kamu mengharamkan yang baik-baik dari apa yang dihalalkan Allah untuk kamu, dan jangan kamu melewati batas, karena sesungguhnya Allah tidak suka kepada orang-orang yang melewati batas” (QS. Al- Maidah: 87).

Alasan lain untuk menabukan kehidupan selibat dalam ajaran Islam adalah pemahaman bahwa pernikahan dapat mengendalikan hawa nafsu manusia, sehingga mereka dapat menjaga kehormatan dirinya (HR. Bukhari).

Tradisi Islam yang menanamkan nilai penting pernikahan lewat berbagai firman Tuhan dan sabda Nabi mencerminkan bahwa tidak ada alasan bagi seorang Muslim untuk tidak melakukan pernikahan. Di kalangan umat Muslim, persyaratan yang harus dipenuhi oleh seseorang yang ingin melakukan pernikahan secara Islam di antaranya adalah: 1) perjanjian antara laki-laki dan perempuan; 2) adanya saksi dan wali nikah dari pihak perempuan; dan 3) mahar dari pihak laki-laki bagi perempuan (HR Bukhari). Tidak ada batasan umur yang jelas bagi calon mempelai laki-laki ataupun perempuan yang akan melangsungkan pernikahan secara Islam. Persyaratan pernikahan Muslim ini tergolong longgar jika dibandingkan dengan hukum perkawinan yang berlaku di Indonesia, dimana pernikahan hanya boleh dilakukan oleh laki-laki yang sudah mencapai umur 19 tahun dan perempuan yang sudah mencapai umur 16 tahun (UU Perkawinan No.1 tahun 1974).

Menurut Geertz, agama adalah "sistem simbol yang beraksi untuk menetapkan suasana hati dan motivasi yang kuat, menyebar, dan tahan lama dalam diri manusia dengan merumuskan konsepsi ihwal tatanan eksistensi umum dan membalut konsepsi ini dengan aura faktualitas, sehingga suasana hati dan motivasi secara unik menjadi tampak realistis” (Geertz, 1973: 90). Simbol, bagi Geertz, mencerminkan dan membentuk dunia. Simbol membentuk dunia dengan cara memunculkan dalam diri pemuja seperangkat disposisi yang khas (kecenderungan, kapasitas, kemampuan, kebiasaan, dll), yang akan menjadi nyata bila individu meyakininya. Perspektif agama, lanjut Geertz, berbeda dari perspektif ilmiah karena ia menyasar kebenaran non-hipotetis tapi juga sekaligus bersifat faktual. Dari sini, muncul arti penting ritual, karena melalui 
rituallah dunia yang ditinggali dan dibayangkan menyatu di bawah seperangkat simbol (Geertz, 1973).

Pernikahan sebagai anjuran agama telah menunjukan adanya keterkaitan antara cara menjalani hidup dan bagaimana gagasan manusia mewarnai pengertian mereka ihwal yang praktis sekaligus bermoral. Pernikahan sebagai ritual kehidupan memiliki arti penting dalam perjalanan hidup manusia. Pernikahan tidak selalu dipandang dari perspektif ekonomi; meskipun tidak sedikit cuitan dan meme $e^{2}$ di media sosial menunjukkan kaitan antara pernikahan dengan ekonomi. Misal, anjuran menikah karena alasan ekonomi (misal: tercukupinya nafkah harian, iming-iming diajak berlibur ke luar negeri, dll), selain tentunya fungsi pernikahan sebagai sarana ibadah. Hal ini menunjukkan betapa media sosial memiliki peran dalam membentuk ulang sebuah makna pernikahan. Peran unik dari media sosial dalam membentuk ulang makna pernikahan memerlukan analisis yang mendalam. Hal yang perlu diperhatikan adalah perubahan bentuk pesan-pesan dalam media sosial terhadap isu tertentu.

Di dalam konteks agama, media massa dan sosial juga memiliki peran penting dalam hal menyampaikan pesan. Seringkali media massa 'mendistorsi' proses pemaknaan yang dialami individu-individu yang mengkonsumsi pesan keagamaan yang disampaikannya. Hal ini mungkin terjadi karena dunia maya tidak memiliki batasan yang konkrit.

\section{Metodologi}

Artikel ini ditulis berdasarkan review literature dan media sosial. Pertama, penulis memulai denganstudi kepustakaan terkait isu yang akan dikaji guna membangun kerangka pemikiran serta observasi pada objek yang akan diteliti di media sosial. Penulis mencari kata kunci dan hashtag 'nikah muda' di media sosial seperti Instagram, Facebook,

\footnotetext{
${ }^{2}$ Meme adalah ide, perilaku, atau gaya yang menyebar dari satu orang ke orang lain dalam sebuah budaya (KBBI).
}

dan Twitter. Penulis kemudian fokus pada konten berupa komentar, meme, dan quote ${ }^{3}$ yang berisi bahasan mengenai nikah muda.

Beberapa saduran mengenai karakter Ridwan Kamil sebagai inisiator penggerak anak muda didapatkan lewat pengalaman pribadi sebagai follower dari akun Instagram Ridwan Kamil. Isu mengenai keberadaan jomblo yang masuk dalam agenda kebijakan pejabat daerah dalam persaingan pemilihan gubernur DKI Jakarta juga turut dibedah karena relevan dengan topik penelitian dan terangkat sebagai isu nasional.

\section{Hasil dan Pembahasan}

Media sosial, sebagai salah satu bentuk media massa kontemporer saat ini, telah berperan menciptakan sebuah gerakan. Hadirnya akun-akun khusus di media sosial yang memiliki fokus terhadap pernikahan dalam Islam ternyata digandrungi oleh banyak remaja. Hal ini terlihat dari jumlah follower yang mencapai ribuan orang. Akun tersebut biasanya dimiliki individual dan atau anonim. Penyebaran gerakan pernikahan oleh akun tersebut disimbolkan lewat berbagai meme dan quote.

Salah satu meme di media sosial yang membahas masalah pernikahan dan menarik untuk disimak adalah meme dari dari akun Instagram @kangabay_4 berikut ini:

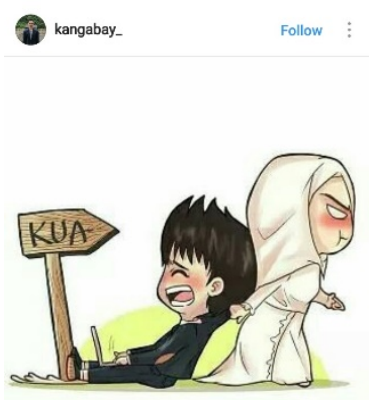

${ }^{3}$ Quote merupakan istilah untuk kutipan kalimat atau ucapan mengenai gagasan seseorang.

${ }^{4}$ Diakses pada 8 Juni 2017 
Gambar 1. Karikatur pengantin pria yang diseret oleh pengantin perempuan dari akun Instagram @kangabay_5

Meme serta quote yang ditampilkan di akun @kangabay tersebut sangat menarik dan tepat sasaran. Pembuatnya telah mengunci target utama pengguna media sosial mereka yaitu: kalangan remaja perempuan Muslim. Hal ini tampak jelas lewat cara penyampaian konsep pernikahan. Misal, karikatur yang digunakan sebagai meme, terlihat menggunakan jilbab. Aktivitas 'menyeret' dapat dimaknai sebagai adanya paksaan terhadap laki-laki untuk mengabulkan keinginan menikah dari pihak perempuan. Dengan kata lain, meme ini bermaksud untuk menyatakan bahwa hidup membujang adalah sebuah abnormalitas di dalam kehidupan bermasyarakat, utamanya, sebuah tindakan yang tidak dianjurkan (atau malah dibenarkan) dalam Islam. Gaya bahasa pada quote di meme tersebut menunjukkan bahwa perempuan ditempatkan pada posisi seseorang yang perlu dinafkahi, sosok yang membutuhkan penghidupan dari laki-laki atau suami.

Di akun lain, @sallyheart ${ }^{6}$ menunjukkan betapa pernikahan setara dengan kebutuhan pokok dan penting, seperti berikut ini:

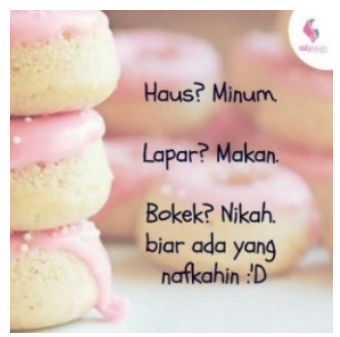

Gambar 2. Salah satu contoh quoteyang diambil dari akunInstagram @sallyheart ${ }^{7}$

Jika kita membedah silogisme yang digunakan oleh pembuat quote di atas, makajelas bahwa kata 'menikah' ditempatkan dalam tingkatan yang sama dengan kebutuhan primer seperti sandang, pangan, dan papan. Artinya, pernikahan tergolong kebutuhan substansial yang harus dipenuhi oleh manusia (terutama perempuan). Dengan kata lain, pernikahan

${ }^{5}$ Diakses pada 8 Juni 2017

${ }^{6}$ Diakses pada 27 Maret 2017

${ }^{7}$ Diakses pada 27 Maret 2017 adalah gerbang untuk memenuhi ketiga kebutuhan primer sekaligus (sandang, pangan, papan).

Pada 2016, masyarakat Indonesia digemparkan oleh pemberitaan di media tentang pernikahan putra sulung dari ustadz Arifin Ilham (Alvin), yang berusia sangat muda. Pernikahan tersebut dianggap cukup kontroversial karena Alvin yang baru berusia 17 tahun dan menikah dengan seorang perempuan mualaf berusia 20 tahun. Dokumentasi pernikahan Alvin dan pasangannya tersiar di berbagai media, terutama televisi dan media sosial. Di dalam akun Instagram-nya, Alvin bahkan turut membagikan ekspresi kebahagiaannya lewat beberapa foto saat prosesi pernikahan berlangsung. Tidak lupa, ia menambahkan keterangan hashtag\#NikahMuda pada caption foto-foto tersebut. Tindakan Alvin memicu sentimen dari netizen yang masih menanti pasangan/ belum menikah. Kebanyakan netizen yang mengetahui pernikahan muda Alvin dan pasangannya memaknai hal ini sebagai tujuan tertinggi dalam sebuah hubungan.
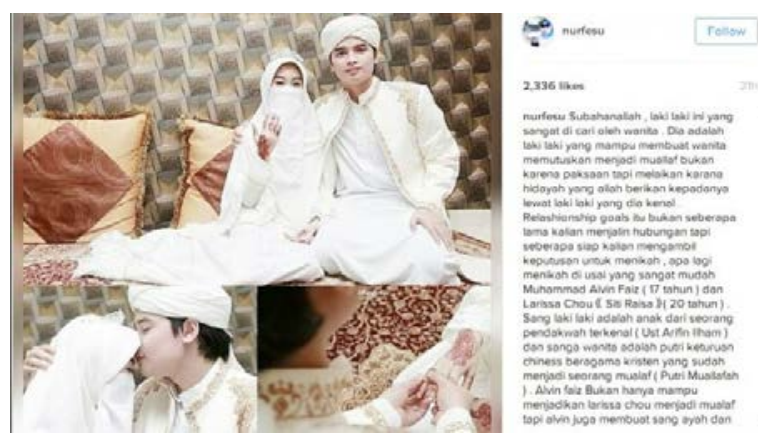

Gambar 3. Repost foto liputan pernikahan dan respons seorang netizen perempuan dalam Instagram@nurfesu ${ }^{8}$

Beredarnya hashtag\#NikahMuda yang sangat viral saat itu dan hadirnya sosok Alvin sebagai pelopor menikah muda di media sosial menunjukkan sebuah fenomena banalitas. Ketika isu pernikahan ditampilkan di media media sosial (lewat meme, foto, dan quote di Instagram), teknik pendekatan edukatif mengenai wacana pernikahan yang dapat dilakukan menjadi terbatas dan cenderung memicu pemahaman yang bias. Nilai

${ }^{8}$ Diakses pada 10 Agustus 2016 
pernikahan tereduksi menjadi sesuatu yang dirayakan tanpa adanya landasan atau pemaknaan yang mendalam. Dengan demikian, pernikahan dianggap seremeh dan segampang aktivitas harian seperti membaca koran, berjalan-jalan di taman, dan sebagainya.

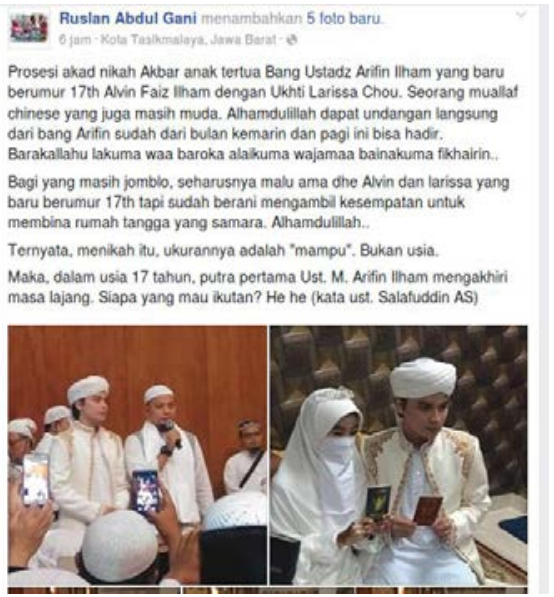

Gambar 4. Repost foto liputan pernikahan dan respons netizen yang menghadiri acara pernikahan Alvin di akun Facebook pribadinya $^{9}$

Wacana pernikahan dan pendiskreditan individu yang masih melajang di media massa sangat laku dan diminati oleh pengguna media sosial. Beberapa pejabat daerah pun turut melirik isu ini dan menyulapnya sebagai program unggulan karena dinilai memiliki prospek besar, jauh melebihi isu klasik seperti pengentasan kemiskinan. Walikota Bandung, Ridwan Kamil, turut membuat kampanye 'ayo menikah' di hadapan para netizen dalam bentuk unggahan di akun Instagram-nya. Ridwan Kamil juga terkenal karena sering menyindir netizen yang belum memiliki pasangan/jomblo lewat foto mesra bersama pasangannya (Atalia Praratya) atau caption yang dibuatnya dalam setiap unggahan.

\footnotetext{
${ }^{9}$ Sumber foto: Nugroho, B. P. (2016, Agustus 06). SaatPutra Sulung Arifin Ilham Menikah di Usia Belia karena 'Mampu'. Diambil kembali dari detiknews: https://news.detik.com/berita/3269818/saat-putrasulung-arifin-ilham-menikah-di-usia-belia-karena mampu (Diakses pada 10 Juli 2017)
}

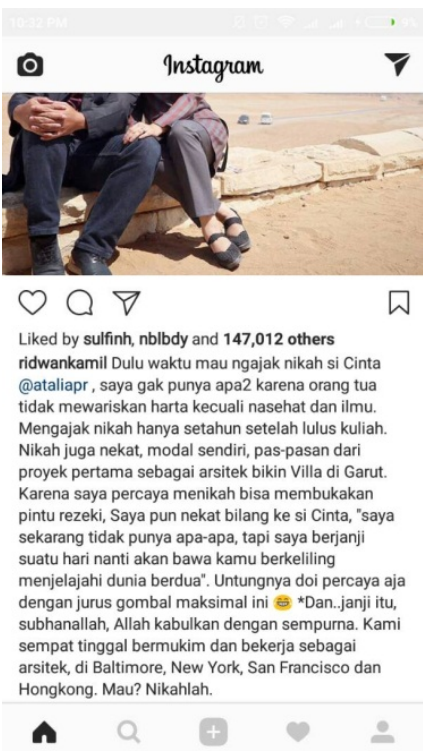

Gambar 5. Salah satu contoh gaya retorika Ridwan Kamil dalam mebuat caption di akun Instagram pribadinya $^{10}$

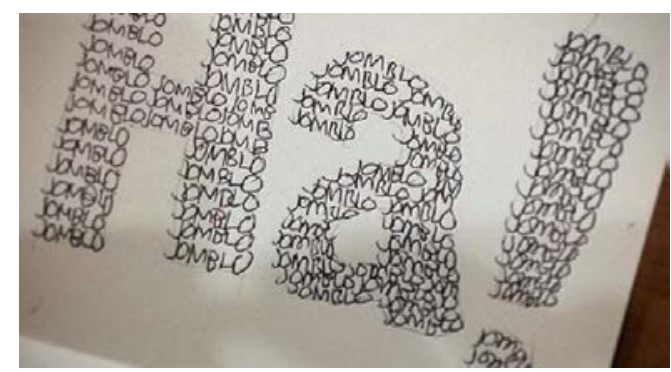

Gambar 6. @ridwankamil: ”Ha! didefinisikan sebagai kata sapaan atau kode yang berarti ia "single and desperate banget. Tag temanmu untuk gabung di PHI (Partai Ha! Indonesia) *Ayo bikin kaosnya" 11

\section{Respons:}

1. @dianisanurulfOke: "Desperate banget ya buu. Tanpa seleksi pun sudah dipastikan lolos komunitas Ha! @raihanammarilis."

2. @rentipusp: "Siapa Siapa tau dpt jodoh disini haha@juwitasitin@daisykarlis @ghitapusparini."12

Ridwan Kamil juga pernah merencanakan untuk membuat partai khusus jomblo, yaitu PHI (Partai Ha! Indonesia), lewat akun

\footnotetext{
${ }^{10}$ Diakses pada 17 April 2017

${ }^{11}$ Mutiah, D. (2016, April 25). Ha!, Partai Jomblo Buatan Ridwan Kamil. Diambil kembali dari Liputan 6: http://regional.liputan6.com/read/2492058/ha-partaijomblo-buatan-ridwan-kamil (Diakses pada 1 Juni 2017)

${ }^{12}$ Diakses pada 10 Juni 2017
} 
Instagram-nya, di mana arti 'Ha!' sendiri didefinisikan oleh Ridwan Kamil sebagai kata sapaan bagi seseorang yang masih single. Kata 'Ha!', sebagai sebuah interjeksi, menyimbolkan kesungguhan perasaan, ketidakpercayaan, ataupun emosi yang kuat ${ }^{13}$. Kata sapa 'Ha!' dipakai untuk menegur para jomblo, untuk memberikan kesan bahwa menjadi jomblo adalah sebuah fenomena yang tidak biasa, di luar kewajaran, tidak terpikirkan, dan mengejutkan. Mengutip dari website regional.liputan6.com (25/4/16), unggahan tersebut langsung disambut ribuan komentar dan sekitar 35.000 like. Netizen lalu menautkan unggahan tersebut kepada rekanrekannya sesama single/jomblo.

Tidak hanya lewat media sosial, wacana jomblo terus digulirkan oleh Ridwan Kamil dan diwujudkan dalam proyek tata kota Bandung. Pada tahun 2014, Ridwan Kamil meresmikan Taman Pasupati dan diperkenalkan pada warga Bandung dengan sebutan Taman Jomblo. Konsep Taman Jomblo telah didesain sesuai dengan nama dari taman tersebut: pemasangan bangku taman yang diperuntukkan untuk diduduki oleh satu orang saja di sepanjang arena taman. Lewat wawancara yang dilakukan oleh surat kabar Kompas (4/1/2014), berikut ini argumentasi Ridwan Kamil sesaat setelah Taman Jomblo diresmikan:

"Pada dasarnya, kami memahami perasaan para jomblo, dan populasinya ternyata sangat banyak di Bandung. Karena, itu saya fasilitasi. Daripada ngelamun atau galau ya, saya kasih tempat supaya bisa kumpul dengan sesamanya (jomblo)". ${ }^{14}$

\footnotetext{
${ }^{13}$ Sesuai dengan Pedoman Umum Ejaan Bahasa Indonesia yang Disempurnakan (EYD)

${ }^{14}$ Perdana, P. P. (2014, Januari 04). Walikota Bandung Resmikan Taman Jomblo. Diambil kembali dari Kompas:

http://regional.kompas.com/read/2014/01/04/1 824494/Wali.Kota.Bandung.Resmikan.Taman.un tuk.Para.Jomblo (Diakses pada 1 Juni 2017)
}

Pasangan gubernur dan wakil gubernur DKI Jakarta terpilih 2017, yaitu Anies Baswedan dan Sandiaga Uno, tidak mau kalah untuk turut memberikan perhatian lebih bagi warganya yang masih hidup melajang. Dilansir dari hasil wawancara oleh jurnalis harian Kompas (2/5/2017), tujuan pasangan ini menggagas program Kartu Jakarta Jomblo adalah untuk memastikan agar setiap warga Jakarta bisa memiliki pasangan hidup. Sandi menjelaskan bahwa program Kartu Jakarta Jomblo adalah program turunan dari program One Kecamatan One Center Enterpreneurship (OK-OCE) dan Rumah DP nol rupiah. Ketika program Kartu Jakarta Jomblo telah terealisasi, diharapkan bahwa angka pengangguran di Jakarta dapat menurun, dan bahwa warga dapat dengan mudah mendapat pasangan lewat bantuan mendapatkan tempat tinggal dan pekerjaan. Dampak lanjutannya: ketika rumah dan pekerjaan sudah dalam genggaman, akan timbul kesan positif di mata calon mertua ${ }^{15}$.

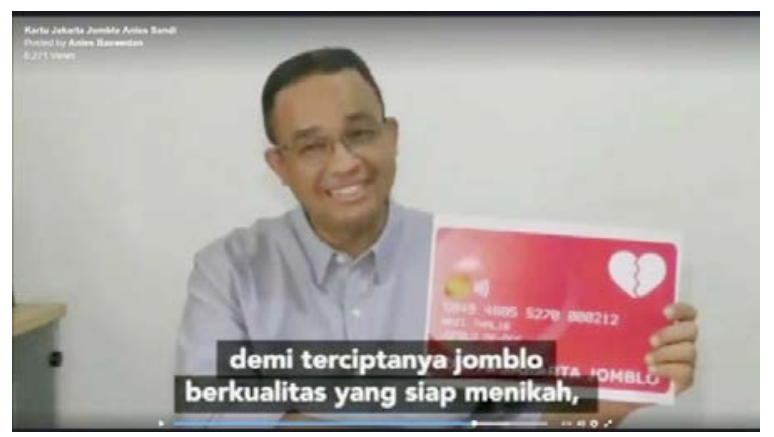

Gambar 7-Kutipan cuplikan video sosialisasi Kartu Jakarta Jomblo oleh Anies Baswedan di akun Youtube pribadinya

Kandidat petahana gubernur DKI Jakarta di masa pilkada 2017 silam, Basuki Cahaya Purnama (Ahok) mengadu program Kartu Jakarta Jomblo yang dibuat oleh pasangan lawan (Sandiaga Uno dan Anies Baswedan) lewat gagasan penambahan jumlah taman di Jakarta. Selain untuk memenuhi jumlah minimal ruang terbuka hijau di Jakarta, keberadaan taman diyakini oleh Ahok dapat mendatangkan pasangan bagi individu yang

${ }^{15}$ Uno, S. (2017, Mei 03). Kartu Jakarta Jomblo, Program Turunan dari OK-OCE dan Rumah DP Nol. (A.Rudi, Pewawancara) 
masih sendiri. Berikut adalah kutipan Ahok dari website Tirto:

"Harusnya di Jakarta itu tidak perlu stres. Jadi jomblo pun menyenangkan hidupnya. Selama memang tidak macet, banyak tempat bisa dikunjungi.

[...] Yang penting Jakarta punya taman yang banyak, punya tempat yang baik, pasti kamu ketemu jodoh.” (April, 2017) ${ }^{16}$

Retorika dan program oleh pemerintah dari dua kota besar di Indonesia ini, secara mencolok memberi fokus lebih pada anak muda yang masih lajang. Hal ini dapat dipahami karena anak muda adalah pengguna internet terbesar di Indonesia. Berdasarkan hasil penelitian yang dilakukan oleh APJII (Asosiasi Penyelenggara Jasa Internet Indonesia) bekerja sama dengan PUSKAKOM (Pusat Kajian Komunikasi Universitas Indonesia) mengenai profil pengguna internet Indonesia di tahun 2014, pengguna internet terbesar adala warga berusia 18-25 tahun (49\%), dengan perbandingan jenis kelamin cukup tipis antara laki-laki dan perempuan, yaitu 49\% dan 51\%. Latar belakang pendidikan pengguna internet didominasi oleh kalangan SMA/sederajat (64,7\%). Data lain mengenai penggunaan internet dan media sosial menunjukkan bahwa pengguna media sosial di Indonesia terbesar ke-4 di dunia. Angka ini diprediksi akan terus meningkat hingga mencakup 42,6\% dari jumlah total penduduk di Indonesia (Sumber data: Statista Digital Market Outlook per Mei 2016).

Lepas dari kepentingan politis yang mendasari retorika dan program pemerintah tentang pernikahan, peran pemerintah yang ikut campur dalam urusan pernikahan menunjukkan betapa pemerintah telah menyusup ke ranah privat warganya. Di Bandung, retorika Ridwan Kamil terkait yang ia raih didorong oleh

\footnotetext{
${ }^{16}$ Jusuf, W. (2017, Mei 05). Mengobral Jomblo di Panggung Politik. Diambil kembali dari Tirto: https://tirto.id/mengobral-jomblo-di-panggungpolitik-cn6x (Diakses pada 1 Juni 2017)
}

pernikahannya, dan hal itu sejalan dengan anjuran agamanya. Di Jakarta, program Sandiaga Uno di Jakarta untuk menyediakan wadah bagi warga yang berstatus single dalam rancangan program ta'aruf ${ }^{17}$ massal juga mengandung logika yang sama: ajakan 'ayo menikah' di media sosial menunjukkan dorongan atau paksaan untuk menikah, yang efeknya terasa semakin kuat karena dibalut oleh aura agama.

Posisi media massa kontemporer telah menjadi saluran gerakan yang dibalut oleh ajaran agama. Cara ini dianggap efektif karena era kini, media massa kontemporer memiliki kekuatan membombardir individu dari segala arah dan mengarahkan perhatian mereka lewat lewat pesan yang terlembagakan (John, 2006). Saat ini, media massa telah memengaruhi segala tindak-tanduk individu (McLuhan, 1965). Alhasil, media massa telah menjadi saluran yang tepat bagi mobilisasi kelompok dan menciptakan sebuah standar moral-universal bagi setiap orang.

\section{Menganalisis pergeseran media dakwah dalam Islam}

Keluarga kini bukan lagi tempat utama terciptanya diskursus tanya-jawab mengenai ajaran agama. Kekosongan peran keluarga kini diisi oleh teknologi. Komunikasi diadik tergantikan produk budaya populer seperti buku, smartphone dan laptop yang membuat individu menjadi individualis. Mengutip Donna Haraway (1991), keterikatan manusia terhadap teknologi disebut sebagai fenomena cyborg (cybernetic organism). Di dalam hal ini, agama turut beradaptasi dengan perubahan zaman, di mana unsur-unsur konservatif dimodifikasi sedemikian rupa agar dapat terlibat dalam kompetisi dengan media massa. Langkah ini ditempuh untuk mengubah imaji agama di ranah publik, sehingga agama tidak lagi dianggap sebagai suatu peninggalan kebudayaan adiluhung tanpa kemampuan untuk menyentuh generasi

\footnotetext{
${ }^{17}$ Ta'aruf adalah tradisi dalam Islam untuk memperkenalkan kedua keluarga dari calon mempelai pria dan wanita sebelum lanjut ke pernikahan
} 
muda dalam bentuk yang lebih segar. Marshall McLuhan (1964) menggambarkan persinggungan ini dengan jargon "media adalah pesan". Media terhubung dengan teknologi pengemasan itu sendiri, yang dibantu kecanggihan teknologi (contoh: teknologi visual, audio) dan kekayaan perbendaharaan citraan yang tersedia, sehingga akhirnya tidak lagi berkaitan dengan dunia realitas yang ingin disampaikan olehnya, serta terjebak dalam mekanisme media yang mengacu pada dirinya sendiri (Fakhruroji, 2010). Dengan kata lain, saat ini individu tergerak untuk menikah karena kesederhanaan pesan dan daya tarik dari media yang mengusung pesan tertentu (pernikahan), alih-alih mendalami hakikat dari pesan yang disampaikan.

Di sisi lain, keberadaan dakwah masih sangat dibutuhkan di era globalisasi ini. Dakwah diharapkan berperan dalam upaya perbaikan moral masyarakat dengan menjadi pengingat hubungan antara manusia dengan Tuhan. Para pelaku dakwah dituntut mampu merespons segala tuntutan dan perubahan sejarah yang terjadi di zaman modern secara tepat (Kahmad, 2002: 68). Perkembangan dakwah setelah Nabi Muhammad wafat menunjukkan perkembangan yang sangat pesat: ketika Nabi masih hidup, berbagai fatwa dan ajaran jihad (termasuk dakwah di dalamnya) harus mengikuti paradigma Nabi dan merujuk pada Al-Qur'an (rujukan asli dari firman-firman Tuhan). Sekarang, ajaran jihad dan otoritas agama/fatwa bersifat lebih longgar karena konsep-konsep tersebut dapat dibuat dan diputuskan oleh cendekiawan, politisi dan orang-orang yang dianggap memiliki pengaruh dalam Islam (Bunt, 2003). Begitupun dengan validasi penyebaran ajaran Islam yang bersumber dari perilaku dan ungkapan yang diutarakan oleh Nabi Muhammad, yang dulunya hanya boleh disebarkan oleh orang-orang tertentu saja (contoh: kalangan sahabat dan keluarga Nabi). Ketika proses penyebaran ajaran agama mulai masuk ke era elektronik, proses individu dalam mencerna sebuah ajaran mengalami percepatan. Individu tidak perlu lagi melewati lapisan kelompok pemegang otoritas ajaran agama karena terbantu oleh adanya persebaran ajaran agama yang telah tersedia di berbagai platform.

Mekanisme ajaran agama kini termediasi pada masyarakat dalam bentuk yang semakin subtil. Peran media massakontemporer dalam ajaran agama saat ini tidak hanya sekadar pedoman hidup yang memberikan instruksi dogmatis, tapi juga merubah cara dan kekuasan yang dimiliki oleh institusi agama serta mengubah cara seseorang dalam berinteraksi dengan orang lain dalam memahami suatu ajaran agama (Hjarvard, 2008: 3). Namun, Hjarvard juga menekankan bahwa ketika suatu ajaran agama disebarkan lewat media massa, nilai ajaran agama tersebut akan tereduksi dengan sendirinya dan berubah menjadi banal, yang menyiratkan bahwa institusi agama tidak lagi memiliki otoritas atas pendistribusian ajaran agama. Dengan kata lain, saat ini agama disubordinasi oleh media massa dalam bentuk dependensi institusi agama terhadap media massa.

Argumen Theodor Adorno (2006) semakin menegaskan bahwa media massa merupakan produk budaya yang memiliki karakter budaya komersial. Imbas dari karakter yang dibawa oleh media massa adalah tergantikannya cara individu berimajinasi oleh mekanisme kontrol media massa yang mampu membuat patokan khusus akan bentuk imaji yang akurat dari sebuah realitas. Kontinuitas hegemoni media massa diteruskan dalam relasi antara pemberi informasi dan penerima informasi: konsumen secara terus menerus dicekoki berbagai informasi sehingga menimbulkan dependensi dari sisi konsumen terhadap produk yang disuguhkan oleh media massa. Implikasi yang dialami konsumen atas perilaku dependensi pada media massa beserta produknya adalah sikap keingintahuan yang menurun. Semua informasi yang diterima individu dianggap suatu kebenaran yang hakiki lewat imaji yang berada di bawah kontrol media massa. Kehadiran media massa kontemporer membentuk manusia menjadi pasif. Individu secara sengaja dibuat untuk tidak memiliki kesempatan dalam memunculkan rasa ingin tahu yang lebih atas suatu informasi. Hal ini merupakan akibat 
dari derasnya arus berita yang menggempur individu lewat berbagai macam media massa kontemporer. Walter Benjamin (1968) telah mengajukan teori serupa mengenai aura. Penerapan konsep aura terhadap fenomena pergeseran media massa dalam ajaran agama dimulai ketika ajaran agama sudah tidak dilakukan lagi seperti sedia kala dan direproduksi lewat media sosial (dalam bentuk meme, quote, dan lain sebagainya). Aura yang dimiliki oleh ajaran agama akhirnya menjadi terdepresiasi. Akan tetapi, berhubung aura hadir tidak secara independen, depresiasi turut dialami oleh nilai kebenaran dan otoritas sebagai aspek yang terkandung pada aura tersebut. Efek dari rentetan domino yang dialami oleh objek hasil reproduksi adalah ketidakseimbangan nilai kebenaran, misrepresentasi, dan munculnya kesalahpahaman. Reproduksi secara masif (information overload) muncul sebagai upaya mendekatkan pengguna media sosial dengan ajaran agama yang telah tereduksi.

Sayangnya, upaya 'kebaikan' tidak selalu menghasilkan 'kebaikan' pula: justru pembanjiran ajaran agama di media sosial membuat hilangnya ruang untuk berkontemplasi. Media sosial menjadi sarana penyebaran ajaran agama yang merdeka karena lepas dari aura ajaran agama yang lalu. Proses ini menghadirkan 'distraksi', dan kemunculan distraksi merupakan sebuah bentuk alternatif dari hilangnya ruang kontemplasi. Dalam media sosial, distraksi diwujudkan dalam bentuk tersedianya kolom comment dan tanda like sebagai bentuk keterlibatan pengguna media. Pernyataan ini menjadi kontra-argumen dari pernyataan Adorno sebelumnya bahwa adanya modernitas hanya membuat manusia menjadi pasif. Meskipun demikian, kolom comment dan like yang tersedia tidak serta-merta menyanggah pasivitas yang menjadi argumen Adorno.

Keterbukaan media massa kontemporer pada akhirnya memang terlihat menjadi arena bagi umat Muslim untuk berkontribusi dan berekspresi atas suatu konsep pemahaman ajaran Islam dalam suatu komunitas yang berada di lintas ruang dan waktu. Bentuk integrasi gaya hidup Muslim modern saat ini melahirkan sebuah lingkungan khusus Muslim di dunia maya yang disebut Cyber Islamic Environtment/CIE (Bunt, 2009). Hibridisasi bahasa dengan ekpresi religiusitas dalam dunia maya memberikan kesempatan bagi umat Muslim untuk menjelajahi kekuatan dari bahasa tulisan dalam berbagai cara yang kreatif, yang akhirnya memunculkan ekspresi religiusitas dalam bentuk jargon, meme, bahasa slang, dan sebagainya dalam CIE sebagai bagian dari produk aliran jaringan Muslim modern (Kepel, 2004).

Model otoritas top-down ala institusi sosial tradisional yang kini dirangkul oleh media sosial berdampak pada cara jaringan komunitas Muslim terbaur ke dalam elemen kebudayaan populer (Anderson, 2001). Saat ini, media massa kontemporer secara sengaja membuat fitur yang ditujukan untuk menciptakan jarak antara pengguna media dengan pembuat konten media. Di Instagram, pengguna media tidak dapat dengan leluasa menyatakan perbedaan pendapat karena tidak tersedianya fitur dislike. Dan meskipun ada fitur comment, otoritas dipegang penuh oleh pembuat konten, misalnya, pembuat konten dapat menghapus komentar dan memblokir akun yang sekiranya telah dirasa mengganggu pembuat konten. Dengan demikian, dialog dan pertukaran antar pendapat yang berbeda-beda tidak bisa dilakukan dengan kebebasan penuh, yang pada gilirannya menyiratkan adanya budaya top-down dalam media sosial dan semacam aktivitas yang pada akhirnya, mengutip Adorno, masih bersifat pasif.

Pergeseran ini juga menyiratkan tantangan bagi status quo institusi sosial tradisional dalam menghadapi keberhasilan berbagai website terkait pengajaran Islam. Bentuk respons positif yang muncul atas komodifikasi pernikahan di dalam media sosial seperti yang telah dikemukakan sebelumnya memberikan bukti bahwa penyebaran ajaran Islam via dunia maya merupakan cara yang sesuai dengan kebutuhan anak muda Muslim. Dengan besarnya frekuensi tingkat akses anak muda terhadap internet dan teknologi, maka mereka akan dengan mudah membentuk CIE bagi kalangan mereka sendiri. Mereka juga dapat turut aktif 
di dalamnya sebagai sarana untuk mengkaji ataupun menjadi pihak yang menyebarkan ajaran Islam tertentu.

Kembali pada persoalan komodifikasi pernikahan di kalangan anak muda, fenomena ini turut diselimuti oleh kegelisahan yang dimiliki oleh individu apabila ia berakhir sebagai lajang seumur hidup. Seperti yang telah disinggung di awal tulisan, julukan 'perawan tua' dan keharusan untuk menikah yang dibalut oleh ajaran agama menjadi teror yang menghantui setiap orang yang belum mendapatkan pasangan hidup di Indonesia. Caryl Rivers (2007) berargumen bahwa media massa hari ini menjual 'kegelisahan', khususnya terkait perempuan yang menjadi korban iklan.

Analisis Rivers berargumen bahwa perempuan sesungguhnya 'membeli' apa yang media inginkan untuk 'dijual', yakni standardisasi kecantikan. Prinsip menjual kegelisahan dalam media massa juga berlaku pada fenomena komodifikasi pernikahan, yakni lewat ajaran agama dalam media sosial. Di satu sisi, kecemasan akan dipicu oleh hegemoni yang dilakukan oleh media massa, dan di sisi lain, tekanan yang disampaikan dalam bentuk ajaran agama akan memiliki kekuatan besar untuk 'memprovokasi' seseorang melalui kesakralan yang terkandung di dalamnya.

Wacana matrimania ini, jika disebarkan secara tidak hati-hati, bahkan bisa menjadi semacam bumerang yang menggagalkan upaya untuk menarik seseorang ke dalam institusi pernikahan. Sebagai salah satu contohnya, wacana matirimania yang terbentuk sering kali berupa kisah-kisah pilu orang yang hidup melajang. Ujungnya, alih-alih membawa dampak positif bagi konsumen media, wacana tersebut malah menimbulkan tekanan dan teror baru pada kepribadian mereka.

Kasus paling riil saat ini adalah meningkatnya fenomena bunuh diri pada kaum laki-laki yang dipicu oleh kekhawatiran bahwa kadar maskulinitas yang mereka miliki tidak memenuhi standar maskulinitas yang berlaku secara sosiokultural (dikenal sebagai toxic masculinity). Seorang laki-laki akan dianggap memenuhi standar maskulinitas apabila ia dapat memiliki pekerjaan yang tetap, mampu membahagiakan keluarga dengan limpahan materi, serta memiliki pasangan hidup (Inhorn, 2003). Lewat pemahaman demikian, maka laki-laki akan berusaha terus untuk mencapai seluruh aspek maskulinitas, yang sebenarnya membuatnya terasing dari dirinya sendiri karena keniscayaan yang diciptakan oleh pihak lain dan yang dibebankan kepadanya secara sinambung.

\section{Simpulan}

Wacana 'ayo menikah' di Indonesia saat ini, atau lebih tepatnya: 'ayo menikah muda ketimbang jomblo terus', bisa dilihat sebagai kontra-argumen nilai-nilai dan budaya Barat, utamanya dalam kasus ini: individualisme yang menganggap pernikahan sebagai pilihan (kalau bukan bentuk pengekangan). Tidak ada keraguan bahwa masyarakat Indonesia telah mengadopsi gaya hidup Barat (misal: cara berpakaian, pola makan, dll) secara eksesif. Namun, agama - dalam bentuk pesan, gagasan, wacana, cara pandang, filsafat, dst - terus tampil ke ranah publik dalam perjuangannya untuk melawan nilai dan budaya ini. Dari sekian banyak aspek yang menjadi sasaran kritik, pernikahan, yakni kewajiban untuk melakukannya atau tidak, menjadi salah satu isu yang paling diperdebatkan di arena publik

Aksi agama yang membonceng media sebagai alat penyebaran pesan-pesannya bukanlah sesuatu yang sifatnya institusional, melainkan lebih ke upaya individual atau semi-individual untuk merangkul modernisasi (sekaligus pada saat bersamaan juga melawannya). Proses perangkulan ini menjadi tak terelakkan, berhubung saat ini media sosial menjadi satu-satunya arena di mana sebuah nilai atau norma bisa tersalurkan dan tersampaikan dengan baik, mudah, dan luas. Dengan demikian, oposisi tak terdamaikan antara agama dan modernisasi yang diyakini oleh teori sekulerisasi tak berlaku dalam kasus Indonesia, karena meskipun dunia dan gaya hidup masyarakat secara kentara menjadi semakin modern, nilai-nilai keagamaan terus 
menemukan celah untuk masuk ke setiap aspek kehidupan, dan bahkan bergerak lebih jauh dengan menyelimuti aspek tertentu dengan aura agama.

Pengekangan ekspresi seksual yang dijustifikasi oleh klaim ajaran Islam dalam wacana pernikahan di media sosial dapat diterima oleh banyak pihak karena didorong oleh pembuktian akan keperempuanan/ kelaki-lakian yang telah didefinisikan oleh masyarakat Indonesia. Di sisi lain, proses pengambilalihan fungsi tradisional dari institusi agama oleh media massa kontemporer tak pelak telah menggerus aspek kontemplatif dan dialogis dari nilai-nilai keagamaan melalui penempatan nilai ini ke dalam logika budaya massa yang pragmatik dan fungsionalistik. Munculnya media sosial dapat mempersatukan imagined community seluruh umat Muslim di seluruh dunia atas dasar kesamaan visi dan ideologi antar mereka, tetapi kualitas konten media sosial sangat belum memadai. Dorongan untuk terus menciptakan produk berita secara instan dan actual membuat media massa kontemporer tidak mampu menyaring dan melakukan studi kepustakaan mendalam konten berita sebaik yang dilakukan oleh media massa tradisional. Media sosial membuat otoritas yang asalnya terdesentralisasi di kalangan ulama kemudian berpindah tangan ke semua orang. Dampaknya adalah banyak agenda reformasi Islam yang tidak melewati kurasi dari pihak pemerintah dan memicu radikalisme. Media sosial mengubah agama menjadi sebuah obat mujarab yang menawarkan pahala instan dan dampak segera. Di sini, corak khas agama yang mendalam, filosofis, dan multi-tafsir akhirnya berubah menjadi satu di Mcluchanmensi, hitam-putih, hegemonik, dan monopolistik.

\section{Daftar Pustaka}

Adorno, T. (2006). The Culture Industry: Selected Essay on Mass Culture. London \& New York: Routledge Classic.

Anderson, J. W. (2001, Agustus 05). Muslim Networks, Muslim Selves in Cyberspace: Islam in the Post-Modern Public Sphere. Diambil kembali dari
Working Papers on New Media and Information Technology in the Middle East:http://www.mafhoum.com/press3/102 S22.htm (Diakses pada 8 Juli 2017)

Benjamin, W. (1968). Illuminations. New York: Hartcourt, Brace \& World.

Bunt, G. R. (2003). Islam in the Digital Age : EJihad, On-Line Fatwas, and Cyber Islamic Environtments. London: Pluto Press.

Bunt, G. R. (2009). iMuslims : Rewiring the House of Islam. USA: The University of North Carolina Press .

Coontz, S. (2006). Marriage, a History: How Love Conquered Marriage. USA: Penguin Books.

Engels, F. (2010). The Origin of The Family, Private Property and The State. New York: Pathfinder Press.

Fakhruroji, M. (2010). Dakwah Islam dan Inovasi Media: Peluang dan Ancaman Media Global Atas Dakwah Islam. KOMUNIKA, 121-129.

Geertz, C. (1973). The Interpretation of Cultures. Basic Books.

Haraway, D. (1991). A Cyborg Manifesto : Science, Technology, and Socialist Feminism. New York: Routledge.

Hjarvard, S. (2008). The Mediatization of Religion: A Theory of The Media as Agents of Religious Change. Northern Lights, 9-26.

Hoebel, E. A. (1949). Man in the Primitive World: An Introduction to Anthropology. New York: Mc Graw-Hill.

John, M. (2006). Media, Mission, and Morality. Washington: Marquette Books.

Kahmad, D. (2002). Tarekat dalam Islam, Spiritualitas Masyarakat Modern. Bandung: Pustaka Setia.

Kepel, G. (2004). The War for Muslim Minds: Islam and the West, (diterjemahkan oleh Pascale Ghazaleh). Cambridge, Mass., and London: Belknap Press of Harvard University Press.

Lo, M., \& Aziz, T. (2009). Muslim Marriage Goes Online : The Use of Internet Matchmaking by American Muslims. Journal of Religion and Popular Culture.

Malinowski, B. (1926). Crime and Custom in Savage Society. London : Kegan Paul, Trench, Trubner \& Co.

Marlowe, F. W. (2003). The Mating System of Foragers in the Standard Cross-Cultural Sample. Cross-Cultural Research 37 (3), 282-306. 
Martos, F. (1982). Doors to The Sacred. New York: Image Books.

McLuhan, M. (1964). Understanding Media : The Extensions of Man. New York: McGraw-Hill.

McLuhan, M. (1965). Essential McLuhan. New York: Basic Books.

Reed, E. (2011). Evolusi Perempuan dari Klan Matriarkal Menuju Keluarga Patriarkal. Jakarta: Kalyanamitra.

Rivers, C. (2007). Selling Anxiety: How the News Media Scare Women. University Press of New England.

Weber, M. (1958). The Protestant Ethic and the Spirit of Capitalism. Los Angeles: Roxbury. 